\title{
Enterobacter cloacae co-infection in a child with primary dengue fever
}

\author{
*V P Sinhabahu ${ }^{1}$, S Chandrasiri ${ }^{2}$, S Wijesekara ${ }^{3}$, K Karunaratne $^{4}$ \\ Sri Lanka Journal of Child Health, 2018; 47(1): 83-85 \\ DOI: http://dx.doi.org/10.4038/sljch.v47i1.8438 \\ (Key words: Dengue, Enterobacter cloacae, secondary bacterial infection)
}

\section{Introduction}

Dengue is the most common arboviral disease worldwide with 58.4 million cases and nearly 13,586 deaths in $2013^{1,2}$. There were 29,777 and 23,781 dengue infections in 2015 and first six months of 2016 respectively with $51 \%$ of cases reported from the Western Province, Sri Lanka ${ }^{3}$.

\section{Case report}

A ten year old previously healthy boy presented with fever, myalgia and headache for 4 days. Urine output was satisfactory. Neck stiffness and photophobia were absent. Examination on day 4 revealed an adequately grown, febrile child with a capillary refill time of less than 2 seconds. Height was on the $50^{\text {th }}$ centile and weight on the $10^{\text {th }}$ centile. Cardiovascular examination showed a pulse rate of 108 /minute, blood pressure $(\mathrm{BP})$ of $100 / 64 \mathrm{mmHg}\left(50^{\text {th }}\right.$ centile $102 / 60 \mathrm{mmHg}$ ) and normal heart sounds. Respiratory, neurological and abdominal systems were normal.

He was managed as for febrile dengue since admission. Urinary catheter was inserted with difficulty due to lack of cooperation of child on day 5 of illness. He became irritable with spiking fever.

\footnotetext{
${ }^{1}$ Senior Registrar in Paediatrics, Professorial Paediatric Unit, Colombo South Teaching Hospital (CSTH), Kalubowila, Dehiwala, ${ }^{2}$ Consultant Microbiologist, CSTH, Kalubowila, Dehiwala, ${ }^{3}$ Senior Lecturer and Consultant Paediatric Neurologist, Professorial Paediatric Unit, CSTH, Kalubowila, Dehiwala, ${ }^{4}$ Consultant Microbiologist, Lady Ridgeway Hospital for Children, Colombo.

*Correspondence: sinbad.1k@gmail.com

(Received on 13 October 2016: Accepted after revision on 18 November 2016)

The authors declare that there are no conflicts of interest

Personal funding was used for the project.

Open Access Article published under the Creative
}

Commons Attribution CC-BY (CC) (P)
Blood was taken for culture and intravenous (IV) cefotaxime started on day 5 . He was started on IV meropenem on day 6 after omitting cefotaxime as he showed clinical deterioration. On day 7, he developed a fever spike of $107^{\circ} \mathrm{F}$ with delirium. BP was recorded as $80 / 44 \mathrm{mmHg}$ with bounding peripheral pulses. Child was treated as septic shock. Conventional blood culture on day 5 and repeat blood culture to BACTEC blood culture system on day 7 revealed coliform species which was identified as Enterobacter cloacae producing extended spectrum beta lactamase (ESBL). It was sensitive to amikacin, imipenem and meropenem and resistant to ampicillin, cefotaxime, cefepime, co-amoxiclav and gentamicin.

Dengue $\operatorname{IgM}$ was positive and Dengue IgG was negative on day 7 of illness which confirmed the diagnosis of primary dengue infection. Lumbar puncture performed on day 10 of illness was blood stained and cerebrospinal fluid (CSF) showed lymphocytes $8 / \mathrm{cu} \mathrm{mm}, \mathrm{RBC} 200 / \mathrm{cu} \mathrm{mm}$, protein 99 $\mathrm{mg} / \mathrm{dl}$ and no sugar difference between CSF and random blood sugar. It was not suggestive of CNS infection. Urine culture taken on day 5 of illness, prior to starting antibiotics, did not show a bacterial growth. Serum ferritin was $836 \mathrm{ng} / \mathrm{ml}$ (Reference range: $20-400)$ and serum fibrinogen level was 2.62 $\mathrm{g} / \mathrm{L}(1.8-3.5)$ on day 7 of illness. Serum ferritin and fibrinogen levels were done to look for evidence of haemophagocytic lymphohistiocytosis (HLH) and results were not suggestive of HLH.

Throughout the hospital stay, child did not show any clinical evidence of plasma leakage. There was no abnormality or evidence of plasma leakage seen in ultrasound scans of abdomen done on day 5, day 6 and day 8 . Summary of investigations are shown in Table 1.

Child was treated with IV meropenem $40 \mathrm{mg} / \mathrm{kg} 8$ hourly for 14 days. Fever settled on day 9 of illness. He made a full recovery from the illness. 
Table 1: Summary of investigations

\begin{tabular}{|l|l|l|l|l|l|l|l|l|}
\hline \multicolumn{1}{|c|}{ Investigation } & Day 2 & Day 4 & Day 5 & Day 6 & \multicolumn{1}{|c|}{ Day 7 } & Day 8 & Day 9 & \multicolumn{1}{|c|}{ Day 10 } \\
\hline White blood cell count per microlitre & 4500 & 2220 & 2250 & 2460 & 4540 & 6300 & 5630 & 5520 \\
\hline Neutrophils (\%) & 55 & 62 & 46 & 84 & 72 & 61 & 55 & 48 \\
\hline Lymphocytes (\%) & 40 & 30 & 47 & 11 & 20 & 31 & 35 & 49 \\
\hline Platelet count per microlitre & 219 & 163 & 147 & 93 & 74 & 99 & 199 & 319 \\
\hline Haematocrit (\%) & 40.1 & 38.8 & 34.8 & 36.8 & 34.5 & 33.2 & 34 & 35.9 \\
\hline Haemoglobin (g/dl) & 13.5 & 13.8 & 13.1 & 12.6 & 11.7 & 11.1 & 12.1 & 13 \\
\hline Alanine transaminase (U/l) & & & 50.8 & 206.6 & 131.9 & 88.3 & & \\
\hline Aspartate transaminase (U/l) & & & 90 & 305.7 & 155 & 81 & & \\
\hline C-reactive protein (mg/l) & & & $<5$ & & 54.4 & & & \\
\hline
\end{tabular}

\section{Discussion}

A study in Singapore showed $0.3 \%$ prevalence of bacteraemia among adult patients with dengue and Staphylococcus aureus was the commonest pathogen ${ }^{4}$. Being critically ill at presentation, comorbidities, advanced age and more severe dengue manifestations are risk factors for bacteraemia in adults $^{4,5}$. A study in Sri Lanka showed that $25 \%$ of adult dengue patients with fever lasting more than 5 days have bacteraemia ${ }^{6}$. Bacterial co-infection increases the morbidity and mortality of dengue. Bacterial co-infections are associated with 14.3$44.4 \%$ mortality ${ }^{5}$. Salmonella typhi co-infection was reported in a child with dengue fever in India ${ }^{7}$.

Enterobacter is a Gram-negative, facultative anaerobic, rod-shaped, non-spore-forming bacterium. Enterobacter aerogenes and Enterobacter cloacae are opportunistic bacteria with clinical significance as nosocomial pathogens especially in intensive care patients ${ }^{8}$. Enterobacter cloacae is the most frequently observed clinical isolate among Enterobacter species $^{8}$. It occurs as commensal microflora in the intestinal tracts of humans and animals ${ }^{8}$. Enterobacter cloacae is resistant to a wide range of antibiotic classes ${ }^{9}$. Culture positivity is higher and time to detection is shorter with BACTEC commercial system compared to conventional blood culture $^{10}$. It was helpful in early diagnosis in our patient. In our patient, Enterobacter cloacae was resistant to multiple antibiotics and possibly hospital acquired Also secondary bacterial infection was not associated with marked leukocytosis in this case. Patients with dengue fever undergo multiple invasive procedures including urinary catheterization, intravenous cannulation and repeated blood sampling. Adherence to strict aseptic techniques and practice of universal precautions are essential to prevent nosocomial infections.

\section{References}

1. Stanaway JD, Shepard DS, Undurraga EA, Halasa YA, Coffeng LE, Brady OJ, et al. The global burden of dengue: an analysis from the Global Burden of Disease Study 2013. Lancet Infectious Disease 2016; 16(6): 712-23.

https://doi.org/10.1016/S14733099(16)0002 6-8

2. Shepard DS, Undurraga EA, Halasa YA, Stanaway JD. The global economic burden of dengue: a systematic analysis. Lancet Infectious Disease 2016; 16(8): 93541.

https://doi.org/10.1016/S14733099(16)0014 6-8

3. Dengue Update. Epidemiology Unit, Ministry of Health. Viewed in:

http://www.epid.gov.lk/web/index.php?optio $\mathrm{n}=\mathrm{com} \_$content\&view $=$article \&id $=171 \% 3 \mathrm{~A}$ dengue-update $\&$ catid $=51 \% 3$ Amessage-forpublic\&Itemid $=487 \&$ lang $=$ en on 2016. 08 . 24

4. Thein TL, Ng EL, Yeang MS, Leo YS, Lye DC. Risk factors for concurrent bacteremia in adult patients with dengue. Journal of Microbiology, Immunology and Infection 2015 Aug 4 (Epub ahead of print).

PMid: 26338309

5. Trunfio M, Savoldi A, Viganò O, Monforte AD. Bacterial coinfections in dengue virus disease: what we know and what is still obscure about an emerging concern. Infection 2016 Jul 22. Viewed in: http://www.ncbi.nlm.nih.gov/pubmed/27448 105 
6. Premaratna R, Dissanayake D, Silva FHDS, Dassanayake M, de Silva HJ. Secondary bacteraemia in adult patients with prolonged dengue fever. Ceylon Medical Journal 2015; 60: $10-12$.

https://doi.org/10.4038/cmj.v60i1.7165

PMid: 25804911

7. Culture proven Salmonella typhi coinfection in a child with Dengue fever: a case report Srinivasaraghavan R, Narayanan $\mathrm{P}$, Kanimozhi T. Journal of Infection in Developing Countries 2015; 9(9):1033-5.

https://doi.org/10.3855/jidc.5230

PMid: 26409747

8. Davin-Regli A, Jean-Marie Pagès. Enterobacter aerogenes and Enterobacter cloacae; versatile bacterial pathogens confronting antibiotic treatment. Frontiers in Microbiology 2015; 6: 392.

https://doi.org/10.3389/fmicb.2015.00392

PMid: 26042091 PMCid: PMC4435039
9. Mezzatesta ML, Gona F, Stefani S. Enterobacter cloacae complex: Clinical impact and emerging antibiotic resistance. Future Microbiology 2012; 7(7):887-902. https://doi.org/10.2217/fmb.12.61 PMid: 22827309

10. Surase PV, Nataraj G, Pattamadai K, Mehta PR, Pazare AR, Agarwal MC, et al. An appropriately performed conventional blood culture can facilitate choice of therapy in resource-constrained settings-comparison with BACTEC $9050 . \quad$ Journal of Postgraduate Medicine 2016 Jun 29. Viewed in: http://www.ncbi.nlm.nih.gov/pubmed/27353 500 